IZA DP No. 5457

The Gender Reservation Wage Gap:

Evidence form British Panel Data

Sarah Brown

Jennifer Roberts

Karl Taylor

January 2011 


\title{
The Gender Reservation Wage Gap: Evidence form British Panel Data
}

\author{
Sarah Brown \\ University of Sheffield \\ and IZA
}

Jennifer Roberts

University of Sheffield

Karl Taylor

University of Sheffield

and IZA

\section{Discussion Paper No. 5457 \\ January 2011}

IZA

P.O. Box 7240

53072 Bonn

Germany

Phone: +49-228-3894-0

Fax: +49-228-3894-180

E-mail: iza@iza.org

\begin{abstract}
Any opinions expressed here are those of the author(s) and not those of IZA. Research published in this series may include views on policy, but the institute itself takes no institutional policy positions.

The Institute for the Study of Labor (IZA) in Bonn is a local and virtual international research center and a place of communication between science, politics and business. IZA is an independent nonprofit organization supported by Deutsche Post Foundation. The center is associated with the University of Bonn and offers a stimulating research environment through its international network, workshops and conferences, data service, project support, research visits and doctoral program. IZA engages in (i) original and internationally competitive research in all fields of labor economics, (ii) development of policy concepts, and (iii) dissemination of research results and concepts to the interested public.
\end{abstract}

IZA Discussion Papers often represent preliminary work and are circulated to encourage discussion. Citation of such a paper should account for its provisional character. A revised version may be available directly from the author. 
IZA Discussion Paper No. 5457

January 2011

\section{ABSTRACT \\ The Gender Reservation Wage Gap: Evidence form British Panel Data*}

Our findings suggest the existence of a gender reservation wage gap. The presence of children, particularly pre-school age children, plays an important role in determining the proportion of this gap that can be explained by individual characteristics. For individuals without children, the unexplained component of the differential is $99 \%$ compared to only $22 \%$ for those with pre-school age children, which might indicate that perceived discrimination in the labour market influences the reservation wage setting of females.

JEL Classification: $\quad \mathrm{J} 13, \mathrm{~J} 24, \mathrm{~J} 64$

Keywords: reservation wages, wage decomposition

Corresponding author:

Karl Taylor

Department of Economics

University of Sheffield

9 Mappin Street

Sheffield S1 4DT

United Kingdom

E-mail: k.b.taylor@sheffield.ac.uk

\footnotetext{
* We are grateful to the ESRC for financial support under grant number RES-000-22-2004 and to the Data Archive, University of Essex, for supplying the British Household Panel Surveys, 1991 to 2008. We are especially grateful to an anonymous referee, Gurleen Popli and Christine Valente for excellent comments.
} 


\section{Introduction and Background}

A vast empirical literature exists exploring the gender wage gap with many studies employing the counterfactual decomposition approach of Oaxaca (1973), which splits the wage differential into an explained component and an unexplained component, with the unexplained component frequently interpreted as discrimination. One unexplored area concerns the potential gender reservation wage differential, which may lead to differences in labour market participation rates between men and women. The reservation wage, the lowest wage at which an individual is willing to work, plays a key role in theoretical models of job search, labour supply and labour market participation (see, e.g., Blackaby et al. 2007). An extensive empirical literature has explored reservation wage setting at the individual level, supporting a positive relationship between reservation wages and the duration of unemployment, with a seminal contribution by Lancaster and Chesher (1983). There is a dearth of studies, however, which have explored the potential gender differences in reservation wage setting. Such analysis may highlight the extent to which men and women harbour different aspirations about labour market wages prior to entry into the labour market, which may reflect perceived wage discrimination in the labour market or different opportunity costs of labour market entry.

\section{Data and Methodology}

We use individual level data from the British Household Panel Survey (BHPS), a nationally representative random sample survey of each adult member from more than 5,000 private households (www.iser.essex.ac.uk/survey/bhps). The analysis is based on an unbalanced panel of data from 1991 to 2008, comprising 12,921 observations, with 53\% of the sample being female. The BHPS contains detailed information on reservation wages at the individual level in each wave: if the respondent 'is not currently working but has looked for work or has not looked for work in last four weeks but would like a job', he/she is asked: 'What is the lowest weekly take home pay you would consider accepting for a job?' Individuals who answer this question are then asked: 'About how many hours in a week would you expect to have to work for that pay?' This enables us to construct the hourly reservation wage which has a mean (standard deviation) of $£ 3.92$ (£1.45) for 
males and $£ 3.58$ (£1.44) for females in 1991 prices. Figure 1 shows the evolution of the real reservation wage over time by gender where there is clearly a differential over the period, with women having lower reservation wages.

The sample comprises those individuals (aged 16-65) not in employment or selfemployment. Out of the sample of individuals who are currently not working and who state that they have looked for work or have not looked for work in the last four weeks but would like a job, $60 \%$ are typically classified as 'economically inactive'. ${ }^{1}$ Individuals are included in the sample if they report a reservation wage, since in so doing they are arguably signaling their attachment to the labour market. Such an approach accords with recent contributions, which recognise that the distinction between unemployment and inactivity may not necessarily be as clear-cut as previously assumed (e.g. Blackaby et al., 2007; Brown et al., 2010).

The reservation wage gap is decomposed as:

$$
\left(\ln \bar{r}_{m}-\ln \bar{r}_{f}\right)=\hat{\beta_{*}}\left(\bar{x}_{m}-\bar{x}_{f}\right)+\left[\bar{x}_{m}\left(\hat{\beta_{m}}-\hat{\beta_{*}}\right)-\bar{x}_{f}\left(\hat{\beta_{f}}-\hat{\beta_{*}}\right)\right]
$$

where $r$ is the real hourly reservation wage, $m$ and $f$ refer to males and females respectively, $x$ is a row vector of observed characteristics, $\hat{\beta}$ is a vector of estimated parameters and a bar denotes a mean value. The term $\hat{\beta_{*}}=\Omega \hat{\beta_{m}}+(1-\Omega) \hat{\beta}_{f}$ represents an estimate of the non discriminatory reservation wage based upon the Oaxaca-Ransom (1994) weighting matrix: $\Omega=\left(x_{m}^{\prime} x_{m}+x_{f}^{\prime} x_{f}\right)^{-1} x_{m}^{\prime} x_{m}$. The first term on the right-hand side of equation (1) represents the difference in the reservation wage that is attributable to individuals' characteristics (explained or endowment component), which typically capture productivity effects, and the second term is that part of the reservation wage differential due to differences in returns to endowments (unexplained

\footnotetext{
${ }^{1}$ The 'economically inactive' group includes: individuals involved in family care; full time students; the long term sick or disabled; and individuals involved in government training.
} 
or discriminatory component). The empirical analysis is based upon the differential being adjusted for sample selection into labour market status. ${ }^{2}$

The control variables in $x$ are: the number of children in the household; number of employees in the household; a quartic in age $;^{3}$ marital status; highest educational attainment; whether in good/excellent health; the regional unemployment rate; ethnicity; years in current spell of unemployment; household labour income; income from financial assets; benefit income; pay in previous employment; and monthly housing costs from mortgage or rent. We also condition upon binary indicators for industry, occupation of previous/last employment and firm size in previous/last job as well as a time trend. ${ }^{4}$ Five different samples are explored in order to investigate the effect of children on the gender reservation wage gap: all individuals; individuals without children; individuals with children; individuals with pre-school children (aged 0 to 4 years); and individuals without pre-school children.

\section{Results}

The findings in Table 1 indicate that there is a positive and statistically significant gender reservation wage gap, although this is generally upwardly biased if selection is unaccounted for. In the sample of all individuals, $78 \%$ of the differential remains unexplained. Of the explained component the most important individual contributing factor is number of children; the negative coefficient on this variable suggests that it narrows the gap between male and female reservation wages, thus children alone account for women having higher reservation wages than men, in contrast to say education where the positive coefficient suggests this variable contributes to

\footnotetext{
2 The instruments used to identify the selection equation are dummy variables for the number of hours per week spent caring, and binary indicators for whether the individual is registered disabled, and/or for whether the health of the individual limits work. These variables are individually and jointly significant in the selection equation but are insignificant when included in the decomposition analysis. The interpretation of the results which follows is independent of controlling for such selection.

${ }^{3}$ Following Murphy and Welch (1990), who explore higher order polynomials in experience in the context of estimating experience-earnings profiles and find support for a quartic specification in years of experience, we include a quartic in age.

${ }^{4}$ Oaxaca and Ransom (1999) show that the decomposition analysis is dependent on the choice of reference category, when conditioning on binary independent variables. Consequently, our analysis is based on methods to transform the coefficients so that the decomposition results are invariant to choice of omitted category (deviation contrast transformation).
} 
widening the reservation wage gap. Estimation of reservation wage models (not reported here) shows that presence of children raises the reservation wage for both men and women, but significantly more for women; in addition women have more children at home than men, hence children narrow the reservation wage gap. This result is inconsistent with Becker's (1985) 'energy model', which suggests that women, particularly those with dependent children, have greater domestic commitments thus diminishing the 'energy' available for paid work (relative to males) culminating in lower wages. Instead our results suggest that children raise the opportunity cost of accepting work outside the home.

Given the importance of children in our results, we split the sample according to presence of children. For those without children, the unexplained component of the reservation wage differential rises to $99 \%$, with the explained component being statistically insignificant, suggesting that perceived discrimination or the costs of labour market entry for those with children may have a large effect here. In contrast, for the sample with children, the unexplained component falls dramatically to $49 \%$. Here the most important factors are number of years in current unemployment spell and pay in previous job, both of which widen the reservation wage gap. Splitting the sample according to the age of the children (reported in Table 2), the explained component rises further to $78 \%$ for those with pre-school children, and is only $26 \%$ for those with children of school age. This suggests that the role of pre-school children is particularly important.

These results may be partly explained by age. Women without children are older (mean age 40) than women with pre-school children (mean age 28). While age is a covariate in our models this cannot control for unobserved expectations and aspirations; the older group of women may have lower expectations based on past experience of discrimination, or they may have other unobserved characteristics that make them less suited to the labour market.

\section{Conclusion}

The analysis suggests the existence of a reservation wage gap between men and women. The presence of children, particularly pre-school children, plays an important role in determining the 
amount of this gap that can be explained by individual characteristics. For individuals without children, virtually none of the gap is explained, whereas for those with children the explained component is $51 \%$ and for those with pre-school children it is $78 \%$. These results may indicate that perceived discrimination in the labour market, particularly for women in their late thirties and early forties, influences reservation wage setting. Our study highlights an important area for future research exploring the labour market aspirations of women.

\section{References}

Becker, G. S. (1985) Human Capital, Effort and the Sexual Division of Labor. Journal of Labor Economics, 3, S33-S58.

Blackaby, D. H., Latreille, P., Murphy, P. D., O’Leary, N. C. and P. J. Sloane (2007) An Analysis of Reservation Wages for the Economically Inactive. Economics Letters, 97, 1-5.

Brown, S., Roberts, J. and K. B. Taylor (2010) Reservation Wages, Labour Market Participation and Health. Journal of the Royal Statistical Society, Series A, 173, 501-29.

Lancaster, T. and A. Chesher (1983) An Econometric Analysis of Reservation Wages. Econometrica, 51, 1661-76.

Murphy, K. M. and F. Welch (1990) Empirical Age-Earnings profiles. Journal of Labor Economics, 8, 202-29.

Oaxaca, R. L. (1973) Male-Female Wage differentials in Urban Labor Markets. International Economic Review, 9, 693-709.

Oaxaca, R. L. and Ransom. M. R. (1994) On Discrimination and the Decomposition of Wage Differentials. Journal of Econometrics, 61, 5-21.

Oaxaca, R. L. and Ransom. M. R. (1999) Identification in Detailed Wage Decompositions. Review of Economics and Statistics, 81, 154-7. 
FIGURE 1: Hourly Real Reservation Wage by Gender

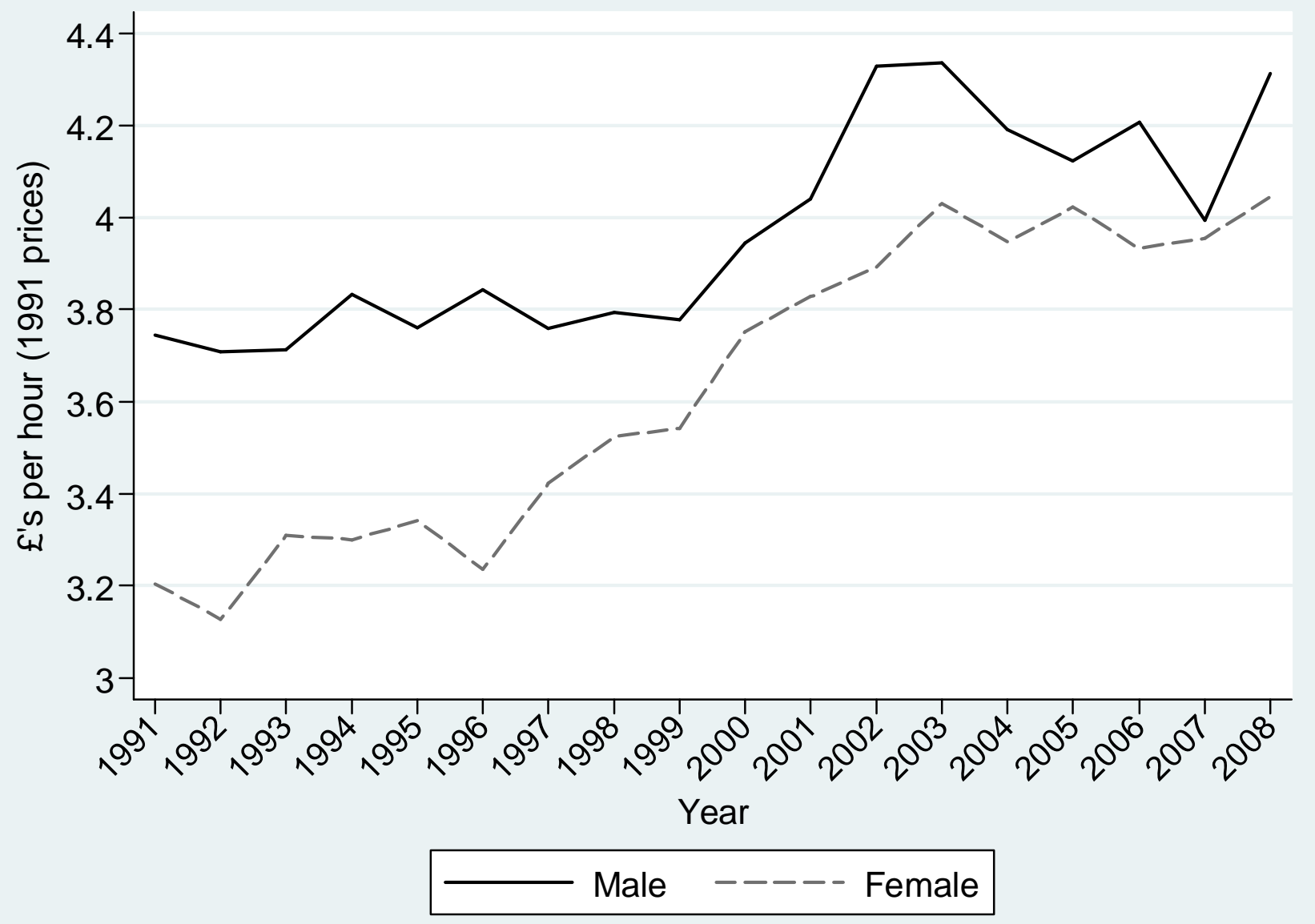


TABLE 1: RESERVATION WAGE GENDER DECOMPOSITION: ALL INDIVIDUALS AND BY CHILD STATUS

\begin{tabular}{|c|c|c|c|c|c|c|c|c|}
\hline \multicolumn{3}{|c|}{$\begin{array}{l}\text { SAMPLE: ALL INDIVIDUALS } \\
\mathrm{n}=12,921 ; \mathrm{n}_{\text {male }}=5,799 ; \mathrm{n}_{\mathrm{female}}=7,122\end{array}$} & \multicolumn{3}{|c|}{$\begin{array}{l}\text { SAMPLE: INDIVIDUALS WITH NO CHILDREN } \\
\qquad \mathrm{n}=6,745 ; \mathrm{n}_{\text {male }}=3,771 ; \mathrm{n}_{\text {female }}=2,974\end{array}$} & \multicolumn{3}{|c|}{$\begin{array}{l}\text { SAMPLE: INDIVIDUALS } \geq \mathbf{1} \text { CHILD } \\
\mathrm{n}=6,167 ; \mathrm{n}_{\text {male }}=2,025 ; \mathrm{n}_{\text {female }}=4,142\end{array}$} \\
\hline & COEF & T STAT & & COEF & T STAT & & COEF & T STAT \\
\hline Male-Female raw differential & 0.091 & 10.680 & Male-Female raw differential & 0.091 & 8.090 & Male-Female raw differential & 0.108 & 8.540 \\
\hline Male-Female sel. differential & 0.087 & 9.400 & Male-Female sel. differential & 0.095 & 7.640 & Male-Female sel. differential & 0.096 & 7.100 \\
\hline Explained (22\%) & 0.019 & 3.510 & Explained (1\%) & 0.008 & 1.280 & Explained $(51 \%)$ & 0.049 & 4.960 \\
\hline Unexplained $(78 \%)$ & 0.068 & 9.250 & Unexplained (99\%) & 0.087 & 8.110 & Unexplained (49\%) & 0.047 & 5.080 \\
\hline Explained & $\%$ & $p$ value & Explained & $\%$ & $p$ value & Explained & $\%$ & $p$ value \\
\hline Number of children & -52.7 & 0.000 & - & & & - & & \\
\hline Number employed in household & 0.4 & 0.810 & Number employed in household & 3.6 & 0.436 & Number employed in household & 1.7 & 0.303 \\
\hline Age & -34.4 & $0.000^{*}$ & Age & -89.1 & $0.003^{*}$ & Age & -2.6 & $0.016^{*}$ \\
\hline Marital status & -5.7 & $0.009^{*}$ & Marital status & -13.9 & $0.149^{*}$ & Marital status & 3.7 & $0.009^{*}$ \\
\hline Education & 28.0 & $0.000^{*}$ & Education & 76.5 & $0.022^{*}$ & Education & -3.6 & $0.016^{*}$ \\
\hline Regional unemployment rate & -4.7 & 0.087 & Regional unemployment rate & -9.5 & 0.216 & Regional unemployment rate & -2.0 & 0.226 \\
\hline Ethnicity & 0.9 & 0.354 & Ethnicity & -0.7 & 0.610 & Ethnicity & 1.7 & 0.103 \\
\hline Current spell unemployment (yrs) & 23.8 & 0.022 & Current spell unemployment (yrs) & 2.9 & 0.958 & Current spell unemployment (yrs) & 17.1 & 0.011 \\
\hline Log household labour income & 10.3 & 0.013 & Log household labour income & 7.8 & 0.261 & Log household labour income & 8.7 & 0.009 \\
\hline Log financial assets & 0.3 & 0.945 & Log financial assets & -14.3 & 0.243 & Log financial assets & -10.1 & 0.001 \\
\hline Log benefit income & -0.2 & 0.773 & Log benefit income & -10.0 & 0.568 & Log benefit income & 2.8 & 0.557 \\
\hline Log pay in previous/last job & 35.6 & 0.000 & Log pay in previous/last job & 37.7 & 0.002 & Log pay in previous/last job & 17.0 & 0.001 \\
\hline Log housing cost & -8.6 & 0.004 & Log housing cost & 3.0 & 0.697 & Log housing cost & -1.5 & 0.192 \\
\hline Time trend & , & 0.938 & Time trend & , & 0.612 & Time trend & , & 0.789 \\
\hline Industry previous/last job & , & $0.015^{*}$ & Industry previous/last job & , & $0.197^{*}$ & Industry previous/last job & , & $0.172^{*}$ \\
\hline Occupation previous/last job & 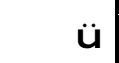 & $0.000^{*}$ & Occupation previous/last job & , & $0.000^{*}$ & Occupation previous/last job & 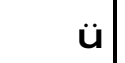 & $0.000^{*}$ \\
\hline Firm size previous/last job & 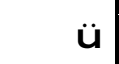 & $0.046^{*}$ & Firm size previous/last job & , & $0.355^{*}$ & Firm size previous/last job & 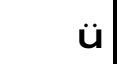 & $0.224^{*}$ \\
\hline
\end{tabular}

Notes: $\mathrm{p}$ values denoted with an asterisk are based upon a joint test of parameters; , signifies the inclusion of controls. 
TABLE 2: RESERVATION WAGE GENDER DECOMPOSITION: PRE-SCHOOL CHILDREN

\begin{tabular}{|c|c|c|c|c|c|}
\hline \multicolumn{3}{|c|}{ SAMPLE: INDIVIDUAL $\geq 1$ CHILD AGED 0-4 } & \multicolumn{3}{|c|}{$\begin{array}{l}\text { SAMPLE: INDIVIDUALS NO CHILDREN AGED 0-4 } \\
\quad \geq \mathbf{1} \text { DEPENDENT CHILD AGED 5+ } \\
\mathrm{n}=3,462 ; \mathrm{n}_{\mathrm{male}}=1,205 ; \mathrm{n}_{\mathrm{female}}=2,257\end{array}$} \\
\hline & COEF & T STAT & & COEF & T STAT \\
\hline Male-Female raw differential & 0.123 & 7.230 & Male-Female raw differential & 0.096 & 5.970 \\
\hline Male-Female sel. differential & 0.113 & 6.090 & Male-Female sel. Differential & 0.078 & 4.530 \\
\hline Explained $(78 \%)$ & 0.088 & 6.050 & Explained (26\%) & 0.020 & 2.590 \\
\hline Unexplained $(22 \%)$ & 0.026 & 2.070 & Unexplained $(74 \%)$ & 0.058 & 4.820 \\
\hline Explained & $\%$ & $p$ value & Explained & $\%$ & $p$ value \\
\hline Number employed in household & 10.8 & 0.037 & Number employed in household & -8.3 & 0.320 \\
\hline Age & 12.0 & $0.024^{*}$ & Age & -79.9 & $0.035^{*}$ \\
\hline Marital status & 5.0 & $0.004^{*}$ & Marital status & 0.6 & $0.800^{*}$ \\
\hline Education & -8.3 & $0.025^{*}$ & Education & 8.0 & $0.272^{*}$ \\
\hline Health & 3.1 & $0.411^{*}$ & Health & 4.5 & $0.816^{*}$ \\
\hline Regional unemployment rate & -1.7 & 0.298 & Regional unemployment rate & -3.3 & 0.529 \\
\hline Ethnicity & 0.7 & 0.363 & Ethnicity & 4.4 & 0.226 \\
\hline Current spell unemployment (yrs) & 1.1 & 0.959 & Current spell unemployment (yrs) & 69.8 & 0.016 \\
\hline Log household labour income & 15.5 & 0.001 & Log household labour income & -6.7 & 0.414 \\
\hline Log financial assets & -15.3 & 0.000 & Log financial assets & -9.4 & 0.105 \\
\hline Log benefit income & 7.8 & 0.173 & Log benefit income & -2.2 & 0.824 \\
\hline Log pay in previous/last job & 15.7 & 0.002 & Log pay in previous/last job & 29.3 & 0.048 \\
\hline Log housing cost & -2.3 & 0.080 & Log housing cost & -0.1 & 0.977 \\
\hline Time trend & , & 0.887 & Time trend & , & 0.646 \\
\hline Industry previous/last job & , & $0.465^{*}$ & Industry previous/last job & , & $0.447^{*}$ \\
\hline Occupation previous/last job & , & $0.073^{*}$ & Occupation previous/last job & , & $0.002^{*}$ \\
\hline Firm size previous/last job & 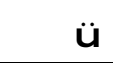 & $0.446^{*}$ & Firm size previous/last job & 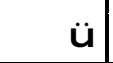 & $0.359^{*}$ \\
\hline
\end{tabular}

Notes: $\mathrm{p}$ values denoted with an asterisk are based upon a joint test of parameters; , signifies the inclusion of controls. 